\title{
ILLUSTRATIONS OF RIGID BODY MOTION ALONG A SEPARATRIX IN THE CASE OF EULER-POINSOT
}

\author{
Adlaj S. F. ${ }^{1}$, Berestova S. A. ${ }^{2}$, Misyura N. E. ${ }^{2}$, E. A. Mityushov ${ }^{2}$ \\ ${ }^{1}$ Federal Research Center "Informatics and Control" \\ ${ }^{2}$ Ural Federal University
}

\begin{abstract}
The aim of our paper is to explain a computer animation of the strictly critical rigid body motion, which ought not be confused with any other motion in its "proximity", however close. We demonstrate that the (local) "uniqueness theorem" remarkably fails in the case of critical motion which (time) domain must be compactified via adjoining the point at (complex) infinity. Two (opposite to each other) "flips" correspond to one and the same (initial) rotation, exclusively either clockwise or counterclockwise, (strictly) about the intermediate axis of inertia. These two symmetrical reversals of the direction of the intermediate axis (of inertia), initially matching then opposing the direction of the (fixed) angular momentum, share one and the same (symmetry) axis, which we call "Galois axis". The Galois axis, which is fixed within the body (but coincides with no principal axis of inertia), rotates uniformly in a plane orthogonal to the angular momentum, as our animation demonstrates. The animation also traces the corresponding two (recurrently selfintersecting) herpolhodes, which turn out to be mirror-symmetrical. The "mirror" is exhibited to lie in a plane, orthogonal to Galois axis at the midst of the "flip". The Galois axis itself is reflected across the minor (or the major) axis of inertia if the direction of the angular momentum is reversed. The formula for the "swing" of the intermediate axis in the plane orthogonal to Galois axis (in body's frame), turns out to be "a square root" of Abrarov's critical solution for a simple pendulum, which (imaginary) period is (exactly) calculated.
\end{abstract}

Keywords: Galois axis, synchronous animation, quaternion.

Citation: S. F. Adlaj, S. A. Berestova, N. E. Misyura, and E. A. Mityushov. "Illustrations of rigid body motion along a separatrix in the case of Euler-Poinsot," Computer tools in education, no. 2, pp. 5-13, 2018.

\section{INTRODUCTION}

A comparative investigation of analytic representations of the solution of the dynamic Euler equations, for the inertial motion of a triaxial rigid body about an axis possessing an intermediate value of the moment of inertia and passing through the center of mass, is performed. Numerical integration of the kinematic equations of the spherical motion of a rigid body is carried out via employing quaternion representation. Four solutions presented in the literature have been exhibited to possess the property of stationary rotation of a special axis, rigidly attached to the body, about the vector of the angular momentum. This axis (the Galois axis) lies in the 
plane perpendicular to the intermediate axis of inertia and its position is determined via the ratios of the principal values of the moments of inertia. The solutions have been exhibited to be obtained one from another via corresponding symmetry transformations. They correspond to opposite initial rotations of the rigid body, as well as, opposite directions of "flips" in the process of intermediate axis direction reversal.

\section{SOLUTIONS OF THE DYNAMIC EULER-POINSOT EQUATIONS FOR MOTION ALONG A SEPARATRIX}

A known classical result in rigid body dynamics is the description of motion via a geometric interpretation, in which the body motion is associated with the motion of a point along curves of the intersection of the surface of constant energy

$$
\frac{1}{2}\left(A p^{2}+B q^{2}+C r^{2}\right)=h
$$

with the sphere

$$
A^{2} p^{2}+B^{2} q^{2}+C^{2} r^{2}=m^{2}
$$

constructed in the coordinates of the angular momentum. Generally, when $m^{2} \neq 2 h B$, these are closed spatial algebraic curves of the fourth order. In the case of $m^{2}=2 h B$ they are intersecting circles. For $A=11, B=21, C=32, m / B=1$ these separatrices are represented in Fig. 1.

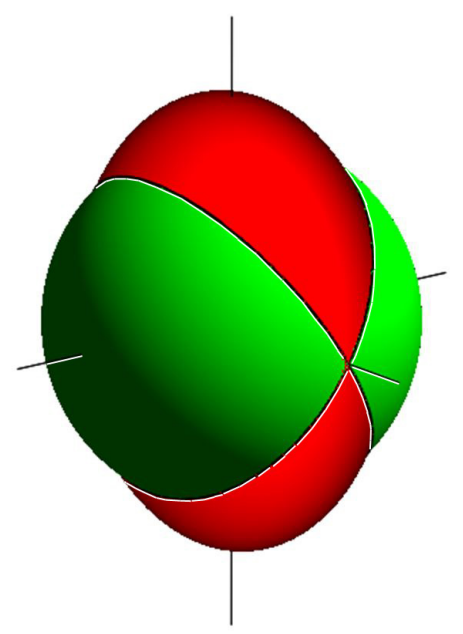

Figure 1. The separatrices are lines of intersecting the surface of constant energy (red) and the surface of the constant angular momentum (green)

If the conditions $A>B>C$, (1), (2), $m^{2} \neq 2 h B$ are satisfied then the functions $p(t), q(t), r(t)$ are expressed explicitly via Jacobi elliptic functions [9]. Alternatively, they might be expressed via the alternative elliptic function, as presented in [3,5]. If $m^{2}=2 h B$, then the rigid body motion is along a separatrix and the solution is written in terms of hyperbolic functions. This coinciding form of solution was repeatedly reproduced in the scientific and educational literature. In 
particular, following the works of [10,11], the solution can be represented in the following form:

$$
\begin{aligned}
& p=\sqrt{\frac{2 h(B-C)}{A(A-C)}} \operatorname{sech} \tau, \quad q=\sqrt{\frac{2 h}{B}} \tanh \tau, \quad r=-\sqrt{\frac{2 h(A-B)}{C(A-C)}} \operatorname{sech} \tau, \\
& p=\sqrt{\frac{2 h(B-C)}{A(A-C)}} \operatorname{sech} \tau, \quad q=-\sqrt{\frac{2 h}{B}} \tanh \tau, \quad r=\sqrt{\frac{2 h(A-B)}{C(A-C)}} \operatorname{sech} \tau, \\
& p=-\sqrt{\frac{2 h(B-C)}{A(A-C)}} \operatorname{sech} \tau, \quad q=\sqrt{\frac{2 h}{B}} \tanh \tau, \quad r=\sqrt{\frac{2 h(A-B)}{C(A-C)}} \operatorname{sech} \tau, \\
& p=-\sqrt{\frac{2 h(B-C)}{A(A-C)}} \operatorname{sech} \tau, \quad q=-\sqrt{\frac{2 h}{B}} \tanh \tau, \quad r=-\sqrt{\frac{2 h(A-B)}{C(A-C)}} \operatorname{sech} \tau,
\end{aligned}
$$

where $\tau=\sqrt{\frac{2 h(B-C)(A-B)}{A B C}}\left(t-t_{0}\right)$.

The works $[8,12]$ are confined to examining only the first of these solutions.

The attainment of an exact and numerically stable solution of the problem of the rigid body motion along the separatrix was achieved via constructing a fourth axis (distinct from the three main axes of inertia), which is called Galois critical axis [4, 5]. It (and only it) rotates uniformly (that is, at a constant angular velocity) about the angular momentum vector, even as the intermediate axis of inertia reverses its direction with respect to the that (constant) vector. The four solutions thus obtained have the form:

$$
\begin{aligned}
p=\frac{m s}{A} \operatorname{sech} \tau, & q=\frac{m}{B} \tanh \tau, & r & =\frac{m c}{C} \operatorname{sech} \tau, & I \\
p=-\frac{m s}{A} \operatorname{sech} \tau, & q=\frac{m}{B} \tanh \tau, & r & =-\frac{m c}{C} \operatorname{sech} \tau, & I I \\
p=\frac{m s}{A} \operatorname{sech} \tau, & q=-\frac{m}{B} \tanh \tau, & r & =-\frac{m c}{C} \operatorname{sech} \tau, & I I I \\
p=-\frac{m s}{A} \operatorname{sech} \tau, & q=-\frac{m}{B} \tanh \tau, & r & =\frac{m c}{C} \operatorname{sech} \tau, & I V
\end{aligned}
$$

where $A<B<C, \tau=\frac{\beta m t}{B}, \beta=\sqrt{\frac{(C-B)(B-A)}{C A}}, s=\sqrt{\frac{A(C-B)}{B(C-A)}}, c=\sqrt{\frac{C(B-A)}{B(C-A)}}$, the position of the Galois axis with respect to the principal axes of inertia of the body is determined by the unit vector $v=(c, 0,-s)$ for the solutions I \& II and the vector $v=(c, 0, s)$ for solutions III \& IV.

The solutions (3) and (4), while distinct in form, are equivalent and their apparent difference is due to the chosen ordering of the moments of inertia $A, B$ and $C$, either ascendingly or descendingly. However, the choice of ordering is elusive in the general case, where $m^{2} \neq 2 h B$, and one ought (in fact) adhere to the ordering imposed via the rule given in [4,5]. In the invariant description of the critical motion, the systems (3) and (4) contain two pairs of identical solutions, which are due to two possible initial positions of the angular momentum with respect to the chosen (inertial) coordinate system. One might also show that in order to obtain the Galois axis, one ought to rotate the minor axis, ${ }^{1}$ in its "initial position", clockwise for an angle arccos c, looking from the end of the vector of the angular momentum.

\footnotetext{
${ }^{1}$ We risk no confusion in our paper as the minor axis of McCullagh ellipsoid (which we employ) does coincide with the principal axis, corresponding to the smallest moment of inertia.
} 


\section{INTEGRATION OF KINEMATIC EQUATIONS}

In order to describe the motion of the body, we use the quaternion parametrization, which allows us to write down the relationship between the coordinates of the unit quaternion and the projections of the angular velocity vector on the axis of the moving coordinate system in the form of a system of linear homogeneous differential equations [7]:

$$
\begin{aligned}
& \dot{\lambda_{0}}=\frac{1}{2}\left(-\lambda_{1} p-\lambda_{2} q-\lambda_{3} r\right), \\
& \dot{\lambda_{1}}=\frac{1}{2}\left(\lambda_{0} p-\lambda_{3} q+\lambda_{2} r\right), \\
& \dot{\lambda_{2}}=\frac{1}{2}\left(\lambda_{3} p+\lambda_{0} q-\lambda_{1} r\right), \\
& \dot{\lambda_{3}}=\frac{1}{2}\left(-\lambda_{2} p+\lambda_{1} q+\lambda_{0} r\right) .
\end{aligned}
$$

The results of integrating these equations on the interval $-8 \pi \leq t \leq 8 \pi$ for the initial conditions $\lambda_{0}(-8 \pi)=1, \lambda_{1}(-8 \pi)=\lambda_{2}(-8 \pi)=\lambda_{3}(-8 \pi)=0$, with the values of the parameters $A=11$, $B=21, C=32$ and $m / B=1$ in the computer algebra system Mathcad 14 with the use of the first equation of system (4) are shown in Fig. 2.
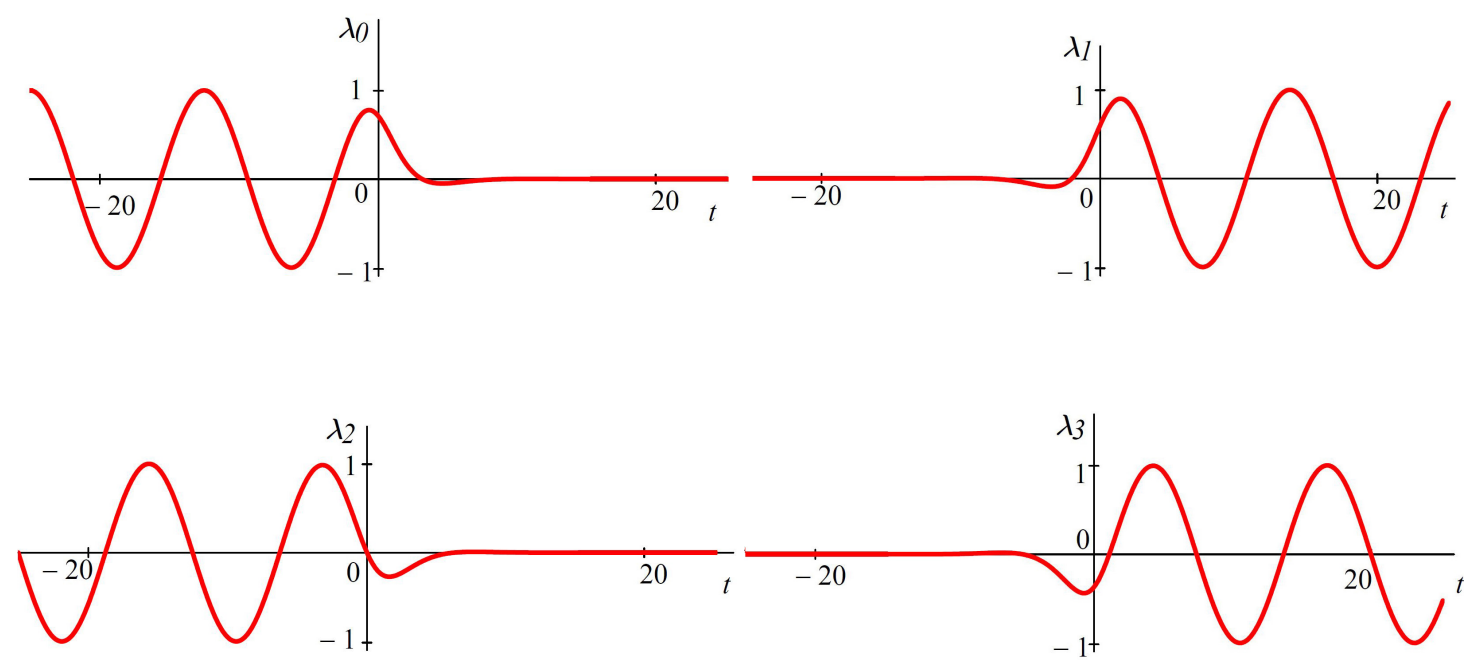

Figure 2. Charts of change of the quaternion coordinates, determining the position of the moving axes of the rotating body

The corresponding screenshot of the program is shown in Fig. 3.

The change in the angular velocity projections onto the moving axes according to the first equation of system (4), for the given parameters, is demonstrated in Fig. 4. 


$$
\begin{aligned}
& \mathrm{A}:=11 \quad \mathrm{~B}:=21 \quad \underset{\mathrm{AMN}}{\mathrm{C}}:=32 \quad \mathrm{~m}_{\mathrm{AMMN}}:=\mathrm{B} \\
& \beta:=\frac{\sqrt{(C-B) \cdot(B-A)}}{\sqrt{C \cdot A}} \quad S:=\sqrt{\frac{A \cdot(C-B)}{B \cdot(C-A)}} \quad S:=\sqrt{\frac{C \cdot(B-A)}{B \cdot(C-A)}} \\
& \text { Given } \\
& \text { to: }:=-8 \pi \quad t 1:=8 \pi \\
& \mathrm{p}(\mathrm{t}):=\frac{\mathrm{m} \cdot \mathrm{s}}{\mathrm{A}} \cdot \operatorname{sech}\left(\frac{\beta \cdot \mathrm{m} \cdot \mathrm{t}}{\mathrm{B}}\right) \quad \mathrm{q}(\mathrm{t}):=\frac{\mathrm{m}}{\mathrm{B}} \cdot \tanh \left(\frac{\beta \cdot \mathrm{m} \cdot \mathrm{t}}{\mathrm{B}}\right) \quad \mathrm{r}(\mathrm{t}):=\frac{\mathrm{m} \cdot \mathrm{c}}{\mathrm{C}} \cdot \operatorname{sech}\left(\frac{\beta \cdot \mathrm{m} \cdot \mathrm{t}}{\mathrm{B}}\right) \\
& \frac{d}{d t} \lambda 0(t)=-0.5 \cdot(\lambda 1(t) \cdot p(t)+\lambda 2(t) \cdot q(t)+\lambda 3(t) \cdot r(t)) \quad \lambda 0(t 0)=1 \\
& \frac{d}{d t} \lambda 1(t)=0.5 \cdot(\lambda 0(t) \cdot p(t)-\lambda 3(t) \cdot q(t)+\lambda 2(t) \cdot r(t)) \quad \lambda 1(t 0)=0 \\
& \frac{d}{d t} \lambda 2(t)=0.5 \cdot(\lambda 3(t) \cdot p(t)+\lambda 0(t) \cdot q(t)-\lambda 1(t) \cdot r(t)) \quad \lambda 2(t 0)=0 \\
& \frac{d}{d t} \lambda 3(t)=0.5 \cdot(-\lambda 2(t) \cdot p(t)+\lambda 1(t) \cdot q(t)+\lambda 0(t) \cdot r(t)) \quad \lambda 3(t 0)=0 \\
& \left(\begin{array}{l}
\lambda_{0} \\
\lambda_{1} \\
\lambda_{2} \\
\lambda_{3}
\end{array}\right):=\text { Odesolve }\left[\left(\begin{array}{l}
\lambda_{0} \\
\lambda_{1} \\
\lambda_{2} \\
\lambda_{3}
\end{array}\right), t, 8 \pi\right]
\end{aligned}
$$

Figure 3. Program screenshot in the computer algebra system Mathcad 14

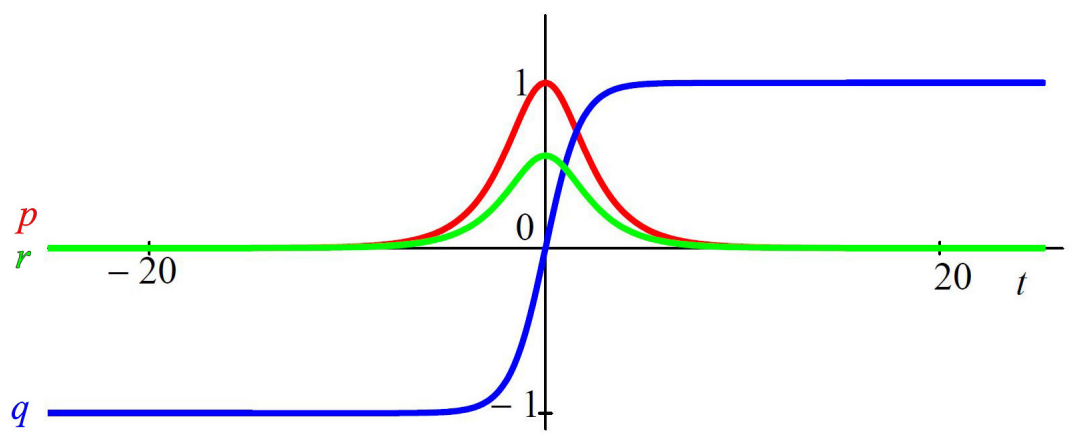

Figure 4. The graphs of the projections $(p, q, r)$ of the angular velocity's vector onto the moving axes: $p$-red, $q$ - blue, $r$ - green 


\section{ILLUSTRATION OF THE MOTION}

The results of integrating the kinematic equations make possible the formation of a functional rotation matrix [6]

$$
R(t)=\left(\begin{array}{ccc}
1-2\left(\lambda_{2}^{2}+\lambda_{3}^{2}\right) & 2\left(\lambda_{1} \lambda_{2}-\lambda_{3} \lambda_{0}\right) & 2\left(\lambda_{0} \lambda_{2}+\lambda_{1} \lambda_{3}\right) \\
2\left(\lambda_{0} \lambda_{3}+\lambda_{2} \lambda_{1}\right) & 1-2\left(\lambda_{3}^{2}+\lambda_{1}^{2}\right) & 2\left(\lambda_{2} \lambda_{3}-\lambda_{0} \lambda_{1}\right) \\
2\left(\lambda_{1} \lambda_{3}-\lambda_{0} \lambda_{2}\right) & 2\left(\lambda_{0} \lambda_{1}+\lambda_{2} \lambda_{3}\right) & 1-2\left(\lambda_{1}^{2}+\lambda_{2}^{2}\right)
\end{array}\right),
$$

as well as, the description of the motion of each point of the rotating body in fixed axes by means of the matrix algorithm

$$
r(t)=R(t) r(-8 \pi) .
$$

Fig. 5 demonstrates the polar plot of the vector of the angular velocity (in green), the trajectory of the intermediate axis and the trajectory of the Galois axis (in red) for all solutions of system (4).

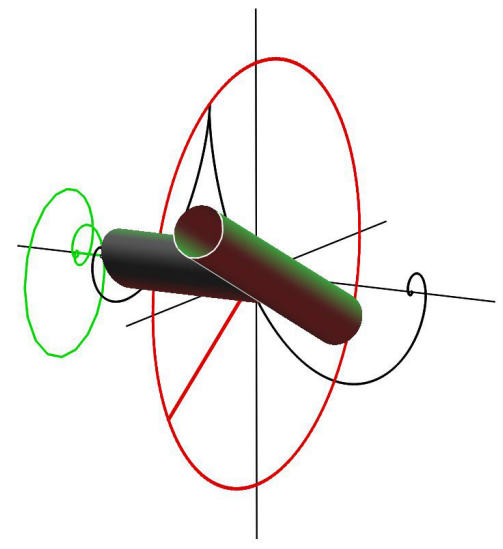

equation I from the system (4)

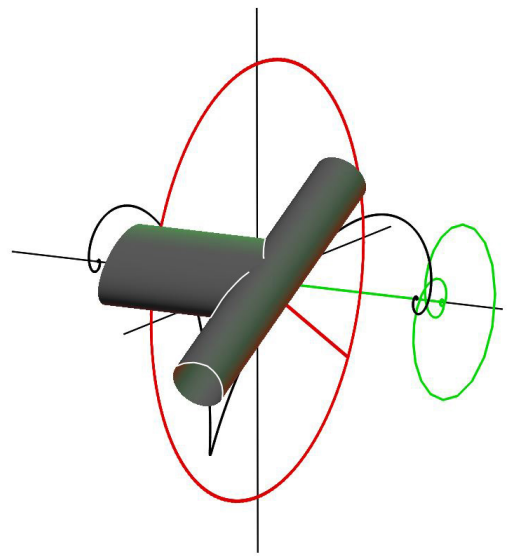

equation III from the system (4)

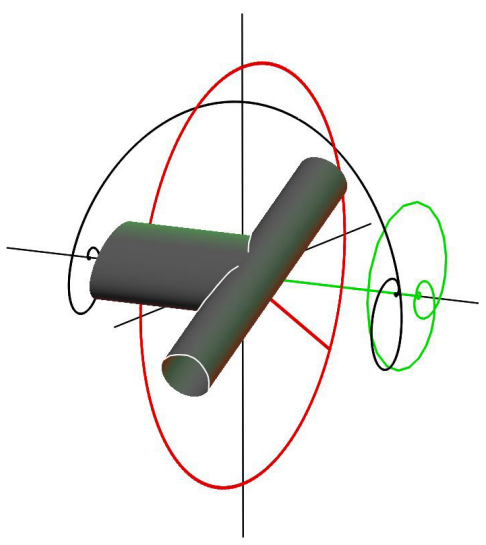

equation II from the system (4)

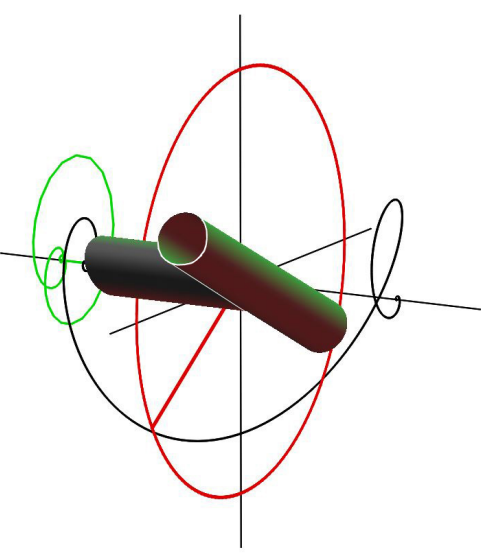

equation IV from the system (4)

Figure 5. The animation frames of the critical rigid body motion along a separatrix

In full, the motion is illustrated by a synchronous animation https://www.youtube.com/ watch?v=c0m_yeKeCiQ. An invariant pair of synchronous solutions is represented by the following synchronous animation https://www.youtube.com/watch?v=e9wGPh-iiRw. 


\section{CONCLUSIONS}

The animation of the critical rigid body motion along a separatrix was posted on Utube (https://www.youtube.com/watch?v=e9wGPh-iiRw) on February 14, 2018. Ten days later, the first comment was posted by Francois Lamarche (McGill University): "very nice indeed, really shows how it keeps rotating with the same angular momentum, but in a completely opposite direction". Two (synchronously) displayed solutions correspond to one and the same initial rotation (exclusively either "clockwise" or "counterclockwise"). Both solutions share one and the same (fixed within the body) uniformly rotating Galois axis, as further clarified in [5]. We emphasize that the law of motion, governing the swing (in a semicircle) of the intermediate axis of inertia in the plane, orthogonal to Galois' axis (in body's frame of reference), is precisely a "square root" of Abrarov's critical motion for a simple pendulum [1-3]. The imaginary period of such critical motion matches (in modulus) $2 \pi B /(\beta m)=2 \pi \sqrt{A B C} / \sqrt{2 h(C-B)(B-A)}$.

\section{References}

1. D. L. Abrarov, Dzeta-model' klassicheskoi mekhaniki. Teoreticheskie i prikladnye aspekty [The Zeta model of classical mechanics. Theoretical and applied aspects], LAP Lambert Academic Publishing, 2016. (in Russian).

2. D. L. Abrarov, "The exact solvability of model problems of classical mechanics in global L-functions and its mechanical and physical meaning," in Mezhdunarodnaya konferentsiya po matematicheskoi teorii upravleniya i mekhanike. Tezisy dokladov. Suzdal', Russia, Jul, 7-11, 2017, pp. 149-150.

3. S. Adlaj, "An analytic unifying formula of oscillatory and rotary motion of a simple pendulum (dedicated to 70th birthday of Jan Jerzy Slawianowski),” in Proc. of Int. Conf. Geometry, Integrability, Mechanics and Quantization, Varna, Bulgaria, Jun. 6-11, 2014, pp. 160-171.

4. S. Adlaj, "Dzhanibekov's flipping nut and Feynman's wobbling plate," in Polynomial Computer Algebra Int. Conf., St. Petersburg, Russia, Apr. 18-23, 2016, pp. 10-14.

5. S. Adlaj, "Torque free motion of a rigid body: from Feynman wobbling plate to Dzhanibekov flipping wingnut” in www.ccas.ru, 2017, [Online], Available: http://www.ccas.ru/depart/mechanics/TUMUS/ Adlaj/FRBM.pdf.

6. A. V. Borisov and I. S. Mamaev, Dinamika tverdogo tela [Rigid body dynamics], Izhevsk, Russia: Regulyarnaya i khaoticheskaya dinamika, 2001 (in Russian).

7. Yu. F. Golubev, Algebra kvaternionov v kinematike tverdogo tela [Quaternion algebra in rigid body kinematics] (Preprinty PM im. M. V. Keldysha. no. 39), Moscow, Russia, 2013, (in Russian), [Online], Available: http://keldysh.ru/papers/2013/prep2013_39.pdf.

8. V. F. Zhuravlev and G. M. Rozenblat, Paradoksy, kontrprimery i oshibki v mekhanike [Paradoxes, counterexamples and errors in mechanics], Moscow, Russia, LENAND, 2017, (in Russian).

9. A. P. Markeev, Teoreticheskaya mekhanika [Analytical mechanics], Izhevsk, Russia: RKhD, 1999 (in Russian).

10. A. P. Markeev, Dinamika tela, soprikasayushchegosya s tverdoi poverkhnost'yu [Dynamics of a body in contact with a rigid surface], Moscow, Russia: Nauka,1992, (in Russian).

11. W. Tong and H. R. Dullin, “A new twisting somersault - 513XD,” Journal of Nonlinear Science, vol. 27, no. 6, pp. 2037-2061, 2017; doi: 10.1007/s00332-017-9403-4.

12. F. L. Chernous'ko, L. D. Akulenko, and D. D. Leshchenko, Evolyutsiya dvizhenii tverdogo tela otnositel'no tsentra mass [Evolution of rigid body motions relative to the center of mass], Moscow-Izhevsk: Izhevskii institut komp’yuternykh issledovanii, 2015.

\section{Video-links}

1. A description of the critical motion of "Dzhanibekov's wingnut” via Galois axis https://www. youtube.com/watch?v=KC3Y8R6m6kU 
2. A computer animation the (dual) critical motion of "Dzhanibekov's wingnut" https://www.youtube. com/watch?v=e9wGPh-iiRw

3. Computer animation two dual "Dzhanibekov's tops” https://www.youtube.com/watch?v=c0m yeKeCiQ

4. Computer animation, demonstrating a triply shared Galois axis https://www.youtube.com/watch? $\mathrm{v}=5 \mathrm{ipE} 5 \mathrm{BB} 0 \mathrm{mA0}$

Received 12.01.2018, the final version - 15.02.2018.

Компьютерные инструменты в образовании, 2018

№ 2: 5-13

УДК: $004.4: 531.01$

http://ipo.spb.ru/journal

\title{
ИЛЛЮСТРАЦИИ ДВИЖЕНИЯ ТВЕРДОГО ТЕЛА ПО СЕПАРАТРИСЕ В СЛУЧАЕ ЭЙЛЕРА-ПУАНСО
}

\author{
Адлай С. Ф. ${ }^{1}$, Берестова С. А. ${ }^{2}$, Мисюра Н. Е. ${ }^{2}$, Митюшов Е. А. ${ }^{2}$ \\ 1 Федеральный научно-исследовательский центр «Информатика и управление» \\ Российской академии наук, Москва, Россия \\ 2урФУ имени первого Президента России Б. Н. Ельцина, Екатеринбург, Россия
}

\begin{abstract}
Аннотация
Цель нашей статьи - пояснить компьютерную анимацию строго критического движения твердого тела, которую не следует путать с каким-либо другим движением в её «окрестности», каким бы близким оно ни было. Мы продемонстрируем, что (локальная) «теорема о единственности» терпит крах в случае критического движения, область определения (времени) которого должна быть компактифицирована присоединением точки (комплексной) бесконечности. Два (противоположных друг другу) «переворачивания» соответствуют одному и тому же (начальному) вращению (строго) относительно оси, с промежуточным моментом инерции, или по ходу часовой стрелки или против неё. Эти две симметричные смены направления промежуточной оси (инерции), первоначально согласующиеся с направлением (фиксированного) углового момента, а затем противонаправлены ему, разделяют одну и ту же ось (симметрии), которую мы называем «осью Галуа». Ось Галуа, жёстко фиксированная в теле (но не совпадающая с какой-либо главной его осью инерции), вращается равномерно в плоскости, ортогональной угловому моменту, как показывает наша анимация. Анимация также отслеживает соответствующие две (рекуррентно самопересекающиеся) герполодии, которые оказываются зеркальносимметричными. «Зеркало» проявляется в плоскости, ортогональной оси Галуа «посреди кувырка». Сама ось Галуа отражается относительно малой (или большой) оси инерции, если направление углового момента меняется на противоположное. Формула «взмаха» промежуточной оси инерции, в плоскости, ортогональной оси Галуа (в системе координат тела), оказывается «квадратным корнем» критического решения Абрарова для математического маятника, (мнимый) период которого (точно) вычисляется.
\end{abstract}

Ключевые слова: ось Галуа, синхронная анимация, кватернион. 
Цитирование: Adlaj S. F., Berestova S. A., Misyura N. E., E. A. Mityushov. Illustrations of rigid body motion along a separatrix in the case of Euler-Poinsot // Компьютерные инструменты в образовании, 2018. № 2. С. 5-13.

Поступила в редакцию 12.01.2018, окончательный вариант - 15.02.2018.

Адлай Семен Франкович, научный сотрудник, Сектор теории устойчивости и механики управляемых систем, Отделение моделирования сложных физических и технических систем, Вычислительный центр им А. А. Дородницына ФИЦ ИУ РАН; 119333, Россия, Москва, ул. ВавилоBa, A. 40, semjonadlaj@gmail.com

Берестова Светлана Александровна, доктор физико-математических наук, заведующая кафедрой теоретической механики УрФу; 620002, Россия, Екатеринбург, ул. Мира, А. 19, s.a.berestova@urfu.ru

Мисюра Наталья Евгеньевна, старший преподаватель кафедры теоретической механики УрФУ; 620002, Россия, Екатеринбург, ул. Мира, д. 19, n_misura@mail.ru

Митюшов Евгений Александрович, доктор физико-математических наук, профессор кафедры теоретической механики УрФу; 620002, Россия, Екатеринбург, ул. Мира, А. 19, mityushov-e@mail.ru

Semjon F. Adlaj,

Scientific Researcher, Section of Stability Theory and Mechanics of Controlled Systems, Division of Complex Physical and Technical Systems Modeling, Computing Center of the Federal Research Center "Informatics and Control", Russian Academy of Sciences; 119333, Russia, Moscow, Vavilov Street 40, semjonadlaj@gmail.com

Svetlana A. Berestova, Doctor of Physics and Mathematics, Head of the Department of Theoretical Mechanics, Ural Federal University; 620002, Russia, Ekaterinburg, Mira Street 19, s.a.berestova@urfu.ru

Natalia E. Misyura,

Senior Lecturer, Department of Theoretical Mechanics, Ural Federal University; 620002, Russia, Ekaterinburg, Mira Street 19, n_misura@mail.ru

Evgenii A. Mityushov, Doctor of Physics and Mathematics, Professor, Department of Theoretical Mechanics, Ural Federal University; 620002, Russia, Ekaterinburg, Mira Street 19, mityushov-e@mail.ru

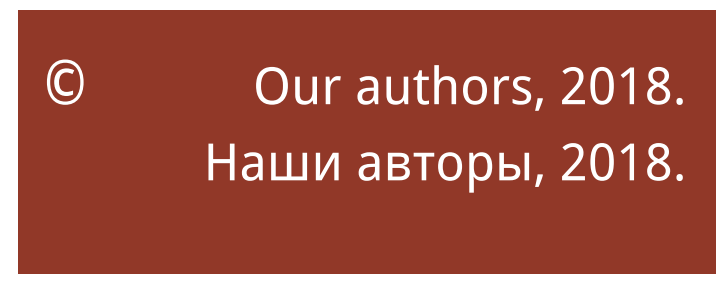

